\title{
EFL Teacher's Perceptions towards Online Learning during COVID-19 Pandemic
} \author{
Ni Komang Christania Wijaya ${ }^{1 *}$, Putu Kerti Nitiasih², Luh Gede Rahayu Budiarta ${ }^{3}$ (D)
${ }_{1,2,3}$ Universitas Pendidikan Ganesha, Singaraja, Indoensia
}

\section{A R T I C L E I N F O}

Article history:

Received September 10, 2021

Revised September 12, 2021

Accepted November 17, 2021

Available online December 25, 2021

Kata Kunci:

EFL Teachers, Perceptions, Online

Learning

Keywords:

Guru EFL, Pembelajaran Daring,

Persepsi

DOI:

http://dx.doi.org/10.23887/jpbi.v9i3.3 8314

\section{A B S T R A C T}

Penerapan pembelajaran online akibat Covid-19 telah menjadi fenomena yang banyak diperbincangkan di dunia pendidikan khususnya dalam proses belajar mengajar bahasa Inggris. Pembelajaran online diterapkan di sekolah masih terdapat kesulitan yang dihadapi oleh guru dan siswa baik secara teknis maupun nonteknis. Evaluasi terhadap pembelajaran online jarang dilakukan, sehingga belum ditemukan solusi yang signifikan untuk mengatasi kesulitan dalam melakukan pembelajaran online. Penelitian ini bertujuan untuk menganalisis persepsi guru EFL terhadap pembelajaran online selama pandemi Covid-19 dengan berfokus pada evaluasi aspek konteks pembelajaran. Metode kualitatif digunakan sebagai desain penelitian dengan mengadaptasi Model CIPPO. Data dikumpulkan melalui beberapa teknik, seperti; observasi, dokumentasi, administrasi angket, dan wawancara. Data yang diperoleh dianalisis secara deskriptif kuantitatif. Hasil penelitian menunjukkan bahwa pelaksanaan pembelajaran online pada masa pandemi covid-19 sudah efektif dan berjalan dengan baik. Namun, guru harus meningkatkan keterampilan mengajar mereka, terutama selama pembelajaran online, untuk membuat siswa bersemangat untuk belajar, terutama dalam belajar bahasa Inggris. Selain itu, guru harus membuat media pembelajaran yang menarik, atau merancang materi pembelajaran yang kreatif untuk menarik perhatian siswa. Di sisi lain, peran keterlibatan orang tua juga penting dalam bidang ini. Hal ini dikarenakan siswa lebih banyak menghabiskan waktunya di rumah. Oleh karena itu, orang tua harus mendukung penuh anak-anaknya, seperti menyediakan smartphone yang sesuai untuk kelas belajar online mereka, juga kouta internet.

This is an open-access article under the CC BY-SA license. Copyright $(2021$ by Author. Published by Universitas Pendidikan Ganesha.

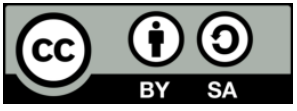

\section{INTRODUCTION}

The world has been rapidly changed by the Covid-19 virus which emerges social distancing as a new policy for people to have a physical distancing to minimize the spread of Covid-19 (Purnama et al., 2021; Pustika, 2020; Saha et al., 2021). This policy also influences the education system where students' interactions in the institutions are limited by the implementation of online learning which persuades students to actively participate in the learning process that can be done remotely from home (Ahmad \& Triastuti, 2021(Maru et al., 2021; Yunita et al., 2021). Online learning is implemented where this program forces Indonesian teachers to change the way of their teachings as the impact of this transition (Meşe \& Sevilen, 2021; Mutohhari et al., 2021; Yani, 2021). Online learning is not a new learning model since it is also perceived as a part of the $21^{\text {st }}$-century learning model considering that teachers and students are not required to do direct interaction but they have learning space without any limitation of time and distance (Bokayev et al., 2020; Putra et al., 2021; Saha et al., 2021). Although, online 
learning has been long introduced in the education system it still dramatically changes the aspect of English language teaching and learning. The English language teaching and learning have been rapidly changed due to the Covid-19 pandemic in which it influences the ways of teachers and students during the teaching and learning process that emerges several challenges, one of them is most of the students are difficulty finishing their studies due to the unusual ways of learning (G. Kim \& Gurvitch, 2020; Kusuma, 2022; Sumedi \& Rovino, 2020). However, online learning also offers several advantages for the teaching and learning process. The usefulness of online learning has been placed in conducting the teaching and learning process during the Covid-19 pandemic in which it assists the educational process without physical contact (Herwin et al., 2022; G. Kim \& Gurvitch, 2020; Prasetya, 2021; Saha et al., 2021). The advantages of online learning, such as; 1) flexibility; it means that the teaching and learning process can be accessed everywhere and anytime, 2) connectivity; it offers students to do online discussion and connect them each other, 3) solution; online learning is also perceived as a solution for overcoming a problem that appears during offline learning (Lase et al., 2021; Liu \& Song, 2021; Rahayu et al., 2020). On another hand, it is also stated that online learning has disadvantages where it is difficult to avoid students doing plagiarism or cheating. Successful online learning depends on the teachers' abilities in mastering and accessing technology in which they are supposed to be able to function and use various techniques for supporting online learning (Nambiar, 2020; Pustika, 2020; Vlachopoulos, 2020)(Kristanto et al., 2021; Udayani et al., 2021). It can be interpreted that teachers still hold an important role to achieve successful online learning by considering the advantages and disadvantages of online learning.

The implementation of online learning due to Covid-19 has been becoming a phenomenon that is widely discussed in the Educational field, particularly in English language teaching and learning. The Indonesian education system has been changed since March 2020 where the online learning has been conducted by using virtual meetings as what has been found in English classrooms where the students have a virtual class by using zoom meeting, google meet, Schoology, Webex, etc during the learning process (B Al-Juda, 2017; Hussein et al., 2020; Khatoony \& Nezhadmehr, 2020). It is conducted for all educational levels, starting from primary school until higher educational level but after one year of implementation, there is still a lack of evaluation conducted to give an overview towards the effectiveness of online learning that has been applied during the Covid-19 pandemic. The problem above is relevant to the preliminary research conducted by the researcher towards the online learning implemented in the rural area, particularly in SMPN 2 Busungbiu and SMPN 5 Busungbiu, Buleleng Regency, Bali. Online learning is applied in this school where Englis is taught as a foreign language through a virtual learning process but it is found out that there are still difficulties faced by teachers and students both technically and nontechnically. Evaluation towards online learning is rarely conducted, therefore there is no significant solution found to overcome the difficulties of conducting online learning. Therefore, evaluation is required to minimize those difficulties.

Several relevant studies have been conducted to give an overview of how the implementation of online learning is conducted in Indonesia. A study that focuses on EFL teachers' perception of the implementation of online learning programs is challenging (Yani, 2021). It is because there is various challenge also the opportunities of teaching are different with a traditional class or face-to-face class like before the pandemic (Nartiningrum \& Nugroho, 2020; Nugroho et al., 2021). There are four main obstacles in the term of conducting online learning especially in teaching English based on the teacher's experiences, such as; unstable connection, lack of ICT skills, economical issues, and limited teaching time. It is continued by the study which shows that EFL teachers assume that conventional learning is more contented considering that they face difficulty in students' inability in understanding the learning materials considering that teachers and students cannot interact directly (Albashtawi et al., 2020; Nartiningrum \& Nugroho, 2020). Online learning emerges several problems and obstacles in teaching English as a foreign language but those problems can be overcome by teachers through packaging the learning material in various interesting ways and joining webinars related to teaching English in online learning during the pandemic situation to improve their teaching skills.

From those studies, it can be seen that most EFL teachers' perceptions indicated the weaknesses of online learning during the pandemic situation (Okmawati, 2020; Yani, 2021). However, further evaluation is required to get more specific information towards the application of online learning in the EFL classroom in which it can be used to minimize the problem faced by teachers and students. Most of the previous studies are conducted through the qualitative method by using interview technique, meanwhile, another significant study is still needed particularly in investigating EFL teachers' perceptions by using the CIPPO evaluation model that consists consist of Context, Input, Process, Product, and Outcome (Yati \& Yaswinda, 2019). This research only focuses on the context aspect as the first component of this study as the newest study considering that there is no recent study that investigates EFL teachers' perception towards online learning by focusing on context evaluation in junior high school. It is underlined by the research question of what the expectations of junior high school teachers in BusungBiu district towards the implementation process of the Online Learning Program by using context evaluation model are. This study aimed at investigating EFL teachers' perceptions toward online learning during the Covid-19 pandemic by focusing on evaluating the context aspect of learning. 


\section{METHOD}

A qualitative method was used by the research design of this study in which the CIPPO evaluative program was selected as the model of this research by focusing on the teachers' perceptions towards the implementation of Online learning in SMP N 2 Busungbiu and SMP N 5 Busungbiu as the object of this study. The settings of this study were SMP N 2 Busungbiu and SMP N 5 Busungbiu by involving two English teachers as a representative from those junior high schools as the subjects. Those teachers were selected by using several criteria as a part of purposive technic sampling. The data were gathered by using the Context evaluation model, particularly by using several techniques of data collection such as; observation, interview, documentation, questionnaire administration, and interview. The gained data were analyzed descriptively quantitatively.

\section{RESULT AND DISCUSSION}

\section{Result}

The total number of respondents of this research are from 2 English teachers, which are from SMPN 2 Busungbiu and SMPN 5 Busungbiu. The purposes of this research are to identify the teacher's perceptive or perception of the online learning program by using a context evaluation model. The data results were described based on the teacher's results questionnaires and supported by results of the teacher's interview with a deeper perspective. The context evaluation related to the teacher's perception towards online learning, included their mastering IT skill, learning platform used during conducting the online learning, the role of parent's involvement during online learning also the characteristic of the school. The results of the teacher's questionnaire data using context evaluation are shown in graph 1.

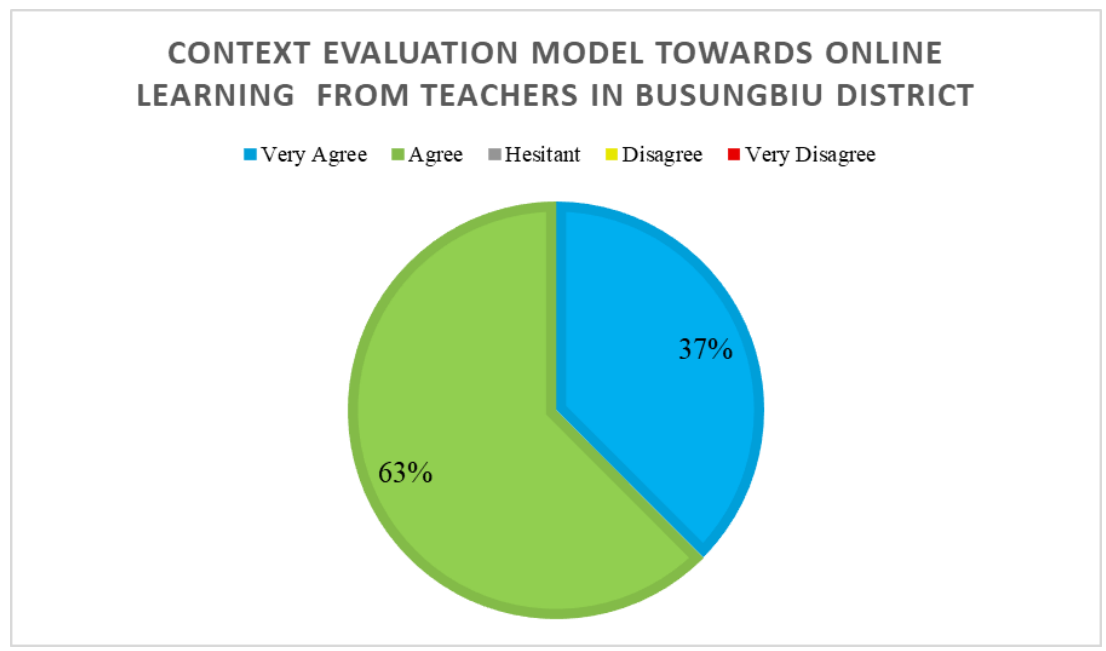

Figure 1. Questionnaire result in context evaluation model from teacher

Based on the chart above, the questionnaire results in context evaluation from two teachers from SMPN 2 Busungbiu and SMPN 5 Busungbiu showed that the teachers are given a positive perspective towards the implementation of online learning. Because $63 \%$ of teachers decided to agree and $37 \%$ decided very disagree. Therefore, the implementation of online learning programs during a covid-19 pandemic is run well or conducted in a good way in the Busungbiu district.

\section{Discussion}

Learning is essentially a process, namely the process of regulating organizing the environment in the area around students so that it can grow and encourage students to carry out the learning process (Abbas et al., 2021; Ao et al., 2019; García-Martínez et al., 2019; Lall \& Datta, 2021; Seibert, 2020). Distance learning requires a medium that can distribute knowledge and as a forum for teaching and learning (Bokayev et al., 2020; Leszczyński et al., 2018; Mamahit, 2020; Sonnenschein et al., 2021). Media containers used in distance learning currently use the internet and a website as a forum for online learning. Online learning can be interpreted as a computer network interconnected with other computer networks throughout the world (Abuhassna et al., 2020; Choi et al., 2021; Fuad et al., 2020; Nugroho et al., 2021). The potential of online learning that can be utilized in everyday life is a communication tool, a tool to access information, and an educational or learning tool. E-learning is a type of 
teaching and learning that allows the delivery of teaching materials to students using the internet, internet, or other computer network media (S.-H. Kim \& Sihyun Park, 2021; Sidhu \& Gage, 2021; Zalat et al., 2021).

Basically, at the beginning of this program start, there are a lot of obstacles faced by the teachers (Primasari \& Zulela, 2021; Windhiyana, 2020). The common problem is the unstable internet connection, mastering IT skills, especially in terms of using online learning platforms with the virtual meeting (Hutauruk \& Sidabutar, 2020; Napsawati, 2020). Yet, because of joining many kinds of workshops that related to online learning, and always practice to use the online learning platform, the teacher can master IT. Fortunately, the online learning in this school already runs well and effectively, although not $100 \%$, at least there is a lot of improvement than last year. The interview above stated that the implementation of online learning in the target school already runs well, although there are various problems faced by the teacher, such as signal, also the mastering the IT skill. Yet, all of the teachers try to improve their IT skills, therefore they can overcome or handle the problem well, therefore they can teach effectively through the online learning platform, even with the virtual meeting, therefore the teacher can control the student's learning process every meeting. On the other hand, it is also useful to make sure that all of the students are serious about learning (Jamaludin et al., 2020; Lestari et al., 2021; Shodiq \& Zainiyati, 2020).

Because this is online learning which is most of the student's time is spent at home, the parent's involvement is very important, sometimes some of the students are complaining that because they were asked to help out in the garden first, or buy something out by their parents (Ro'fah et al., 2020; Slovaček \& Čosić, 2020). Therefore, learning is disrupted, so we are here to give you relief from collecting assignments until $6 \mathrm{pm}$. If there are children who have problems during online learning, we also call parents to school. Therefore, it is easier for teachers if parents supervise their children from home, so teachers and parents have good cooperation in supervising student learning activities at home when online (Jannah \& Umam, 2021; Kurniati et al., 2020). From the interview above the teacher stated that the parents' involvement is very important in this situation, which is in joined online learning. It is because the students are spent most of their time at home. Therefore, the parents should fully support their children, it can be served the learning facilities, and give them a motivation to learn, to make the students are effective in joined their online class. Although, the teacher also controlled their learning progress. The students are quite potential, the learning facilities are quite adequate, the students are friendly, the environment is comfortable. The characteristics of this school are that the children here are very polite, friendly and all responsible here. From the interview above, it is shown that the characteristic of the target school is good, which is they have a polite, also friendly students and for the school facilities to support the learning also good. Yet, the teacher should be improving their teaching skills, especially during online learning, to make the students excited to learn, especially in learning English (Bedir, 2019; Soisangwarn \& Wongwanich, 2014). Besides, the teacher should create interesting teaching media, or design a creative learning material to catch the student's attention. On the other hand, the role of parents' involvement is also important in this field. It is because the students are spent most of their time at home. Therefore, the parents should be fully supported their children, such as serving them an appropriate smartphone for their online learning class, also the internet Kouta.

\section{CONCLUSION}

This research is explained further the teacher's perception towards the implementation of online learning in junior high school, particularly in the Busungbiu district by using the context evaluation model. Based on the data, the teacher showed a positive perspective about the online learning conducted in the target school. It is because the teachers can handle and overcome the problem faced at the beginning of this program implemented well. Therefore, the implementation of online learning during the covid-19 pandemic in Busungbiu district, particularly in SMPN 2 Busungbiu and SMPN 5 Busungbiu are effective and run well.

\section{REFERENCES}

Abbas, H., Janjua, F., Masood, A., Rashid, I., \& Khan, M. M. Z. M. (2021). Textual analysis of traitor-based dataset through semi-supervised machine learning. Future Generation Computer Systems, 125. https://doi.org/10.1016/j.future.2021.06.036.

Abuhassna, H., Al-rahmi, W. M., Yahya, N., Aman, M., \& Megat, Z. (2020). Development of a new model on utilizing online learning platforms to improve students' academic achievements and satisfaction. International Journal of Educational Technology in Higher Education, 17(73), 2-23. https://doi.org/10.1186/s41239-020-00216-z.

Ahmad, P., \& Triastuti, A. (2021). EFL Teachers' Experiences During the Pandemic: Stories From Rural Area in Tungkal Ilir District. IJEE (Indonesian Journal of English Education), 8(2), 297-308. https://doi.org/10.15408/ijee.v8i2.22409. 
Albashtawi, A., Ham Albashtawi, A. H., \& Bataineh, A. (2020). The effectiveness of google classroom among EFL students in Jordan: An innovative teaching and learning online platform. International Journal of Emerging Technologies in Learning, 15(11), 78-88. https://doi.org/10.3991/IJET.V15I11.12865.

Ao, J., Li, N., \& Ma, C. B. (2019). Q-Learning-Based Spinal Code Transmission Strategy in Long Distance FSO Communication. Procedia $\quad$ Computer 154. https://doi.org/10.1016/j.procs.2019.06.030

B Al-Juda, M. Q. (2017). Distance Learning Students' Evaluation of E-Learning System in University of Tabuk, Saudi Arabia. Journal of Education and Learning, 6(4), 324. https://doi.org/10.5539/jel.v6n4p324.

Bedir, H. (2019). Pre-service ELT teachers' beliefs and perceptions on 21st century learning and innovation skills (4Cs). Journal of Language and Linguistic Studies, 15(1), 231-246. https://doi.org/10.17263/j1ls.547718.

Bokayev, B., Torebekova, Z., Abdykalikova, M., \& Davletbayeva, Z. (2020). Exposing policy gaps: the experience of Kazakhstan in implementing distance learning during the COVID-19 pandemic. Transforming Government: People, Process and Policy, 15(2), 275-290. https://doi.org/10.1108/TG-07-2020-0147.

Choi, J. J., Robb, C. A., Mifli, M., \& Zainuddin, Z. (2021). University students' perception to online class delivery methods during the COVID-19 pandemic: A focus on hospitality education in Korea and Malaysia. Journal of Hospitality, Leisure, Sport and Tourism Education, 29(August), 100336. https://doi.org/10.1016/j.jhlste.2021.100336.

Fuad, M., Ariyani, F., Suyanto, E., \& Shidiq, A. S. (2020). Exploring teachers' tpck: Are indonesian language teachers ready for online learning during the covid-19 outbreak? Universal Journal of Educational Research, 8(11B), 6091-6102. https://doi.org/10.13189/ujer.2020.082245.

García-Martínez, I., Fernández-Batanero, J. M., Sanchiz, D. C., \& de la Rosa, A. L. (2019). Using mobile devices for improving learning outcomes and teachers' professionalization. Sustainability (Switzerland), 11(24), 1-12. https://doi.org/10.3390/su11246917.

Herwin, H., Fahturrohman, F., Wuryandani, W., Dahalan, S. C., Suparlan, S., \& Kurniawati, K. (2022). Evaluation of structural and measurement models of student satisfaction in online learning. International Journal of Evaluation and Research in Education (IJERE), 11(1), 152-160. https://doi.org/10.11591/ijere.v11i1.22115.

Hussein, E., Daoud, S., Alrabaiah, H., \& Badawi, R. (2020). Exploring undergraduate students' attitudes towards emergency online learning during COVID-19: A case from the UAE. Children and Youth Services Review, 119(10), 105699. https://doi.org/10.1016/j.childyouth.2020.105699.

Hutauruk, A., \& Sidabutar, R. (2020). Kendala pembelajaran daring selama masa pandemi di kalangan mahasiswa pendidikan matematika: Kajian kualiatatif deskriptif. Journal of Mathematics Education and Applied, 02(01), 45-51. https://doi.org/10.36655/sepren.v2i1.364.

Jamaludin, G. M., Supriatna, D., \& Burhani, A. Z. (2020). the Effect of Online Learning System During the Covid-19 Pandemic on Students' Learning Motivation and Interest in Learning. Jurnal Tatsqif, 18(2), 169-182. https://doi.org/10.20414/jtq.v18i2.2795.

Jannah, N., \& Umam, K. (2021). Peran Orang Tua dalam Pendidikan Karakter Berbasis Keluarga di Masa Pandemi Covid-19. FALASIFA : Jurnal Studi Keislaman, 12(1), 95-115. https://doi.org/10.36835/falasifa.v12i1.460.

Khatoony, S., \& Nezhadmehr, M. (2020). EFL teachers' challenges in integration of technology for online classrooms during Coronavirus (COVID-19) pandemic in Iran. AJELP: Asian Journal of English Language and Pedagogy, 8(2), 1-16. https://doi.org/10.37134/ajelp.vol8.sp.1.2020.

Kim, G., \& Gurvitch, R. (2020). Online Education Research Adopting the Community of Inquiry Framework: A Systematic Review. Quest, 72(4), 395-409. https://doi.org/10.1080/00336297.2020.1761843.

Kim, S.-H., \& Sihyun Park. (2021). Influence of Learning Flow and Distance E-Learning Satisfaction on Learning Outcomes and the Moderated Mediation Effect of Social-Evaluative Anxiety in Nursing College Students during the COVID-19 Pandemic: A Cross-Sectional Study. Nurse Education in Practice, 6(103197). https://doi.org/10.1016/j.nepr.2021.103197.

Kristanto, A., Sulistiowati, ., \& Pradana, H. D. (2021). Brain-Based Online Learning Design in The Disruptive Era for Students in University. Journal of Educational and Social Research, 11(6), 277. https://doi.org/10.36941/jesr-2021-0147.

Kurniati, E., Nur Alfaeni, D. K., \& Andriani, F. (2020). Analisis Peran Orang Tua dalam Mendampingi Anak di Masa Pandemi Covid-19. Jurnal Obsesi: Jurnal Pendidikan Anak Usia Dini, 5(1), 241. https://doi.org/10.31004/obsesi.v5i1.541. 
Ni Komang Christania Wijaya ${ }^{1}$, Putu Kerti Nitiasih ${ }^{2}$, Luh Gede Rahayu Budiarta ${ }^{3}$ (2021). Jurnal Pendidikan Bahasa Inggris Undiksha. Vol. 9(3) PP. 318-324

Kusuma, I. P. I. (2022). EFL Teachers' Online Teaching in Rural Schools during the COVID-19 Pandemic : Stories from Indonesia. Studies in English Language and Education, 9(1), 203-221.

Lall, M., \& Datta, K. (2021). A pilot study on case-based learning (CBL) in medical microbiology; students perspective. Medical Journal Armed Forces India, 77(1). https://doi.org/10.1016/j.mjafi.2021.01.005.

Lase, D., Zega, T. G. C., \& Daeli, D. O. (2021). Parents' Perceptions of Distance Learning during COVID19 Pandemic in Rural Indonesia. SSRN Electronic Journal, 13(2), 101-111. https://doi.org/10.2139/ssrn.3890610.

Lestari, K. B., Dwi Lestari, I. F., \& Santoso, I. (2021). The Impact of Health Education Using Online Learning on Adolescent Knowledge of Anaemia. KnE Social Sciences, 2021, 209-220. https://doi.org/10.18502/kss.v5i3.8541.

Leszczyński, P., Charuta, A., Łaziuk, B., Gałązkowski, R., Wejnarski, A., Roszak, M., \& Kołodziejczak, B. (2018). Multimedia and Interactivity in Distance Learning of Resuscitation Guidelines: A Randomised Controlled Trial. Interactive Learning Environments, 26(2), 151-162. https://doi.org/10.1080/10494820.2017.1337035.

Liu, H., \& Song, X. (2021). Exploring "Flow" in young Chinese EFL learners' online English learning activities. System, 91. https://doi.org/10.1016/j.system.2020.102425.

Mamahit, C. E. J. (2020). Blended Model of Distance Learning: Does It Effective ? Jurnal Pendidikan Teknologi Kejuruan, 3(4), 176-186. https://doi.org/10.24036/jptk.v3i4.15223.

Maru, M. G., Pikirang, C. C., \& Wuntu, C. (2021). Teachers ' Perspectives of Autonomous Behavior in Language Learning : A Survey among English Teachers. Jurnal Bahasa Sastra Dan Pengajarannya Universitas; A Survey among English Teachers, 15(2). https://doi.org/10.31849/reila.v3i1.6064.

Meşe, E., \& Sevilen, Ç. (2021). Factors influencing EFL students' motivation in online learning: A qualitative case study. Journal of Educational Technology \& Online Learning, 4(1), 11-22. https://doi.org/10.31681/ jetol.817680.

Mutohhari, F., Sudira, P., \& Nurtanto, M. (2021). Automotive Engineering Drawing Learning: Effective Online Learning Using Autocad Application. Journal of Education Technology, 5(2), 214-219. https://doi.org/10.23887/jet.v5i2.33197.

Nambiar, D. (2020). The impact of online learning during COVID-19 : students ' and teachers 'perspective. The International Journal of Indian Psychology, 8(2), 783-793. https://doi.org/10.25215/0802.094.

Napsawati, N. (2020). Analisis Situasi Pembelajaran IPA Fisika Dengan Metode Daring Di Tengah Wabah Covid-19. Karst: Jurnal Pendidikan Fisika Dan Penerapannya, 3(1), 96-102. https://doi.org/10.46918/karst.v3i1.546.

Nartiningrum, N., \& Nugroho, A. (2020). Online Learning amidst Global Pandemic: EFL Students ' Challenges , Suggestions, and Needed Materials. Academic Journal of English Language and Education, 4(2), 115-140. https://doi.org/10.29240/ef.v4i2.1494.

Nugroho, A., Ilmiani, D., \& Rekha, A. (2021). EFL Teachers' Challenges and Insights of Online Teaching amidst Global Pandemic. Metathesis: Journal of English Language, Literature, and Teaching, 4(3), 277. https://doi.org/10.31002/metathesis.v4i3.3195.

Okmawati, M. (2020). The Use of Google Classroom during Pandemic. Journal of English Language Teaching, 9(2), 438. https://doi.org/10.24036/jelt.v9i2.109293.

Prasetya, R. E. (2021). Engagement Strategies in Electronic Tools English Online Learning: Higher Education Context. IJEE (Indonesian Journal of English Education), 8(2), 309-326. https://doi.org/10.15408/ijee.v8i2.22358.

Primasari, I. F. N. D., \& Zulela. (2021). Kendala Pembelajaran Jarak Jauh (PJJ) Secara Online Selama Masa Pandemik Covid-19 di Sekolah Dasar. JIKAP PGSD: Jurnal Ilmiah Ilmu Kependidikan, 5(1), 64 73. https://doi.org/10.26858/jkp.v5i1.16820.

Purnama, S., Ulfah, M., Machali, I., Wibowo, A., \& Narmaditya, S. B. (2021). Does digital literacy in fl uence students , online risk? Evidence from Covid-19. Heliyon, 7(6), 2-6. https://doi.org/10.1016/j.heliyon.2021.e07406.

Pustika, R. (2020). Future English teachers' perspective towards the implementation of e-learning in the covid-19 pandemic era. Journal of English Language Teaching and Linguistics, 5(3). https://doi.org/10.1371/journal.pone.0248758.

Putra, I. G. K. M., Santosa, M. H., \& Pratiwi, N. P. A. (2021). Students' perceptions on online peer feedback practice in EFL writing. Indonesian Journal of English Education, 8(2), 213-231. https://doi.org/10.15408/ijee.v8i2.21488.

Rahayu, R., Puji, E., \& Wirza., Y. (2020). Teachers' perception of online learning during pandemic covid19. Jurnal Penelitian Pendidikan, 20(3). https://doi.org/10.17509/jpp.v20i3.29226. 
Ro'fah et al. (2020). Is Online Learning Accessible During COVID-19 Pandemic ? Voices and Experiences of UIN Sunan Kalijaga Students with Disabilities. Nadwa: Jurnal Pendidikan Islam, 14(1), 1-38. https://doi.org/10.21580/nw.2020.14.1.5672.

Saha, A., Dutta, A., \& Sifat, R. I. (2021). The mental impact of digital divide due to COVID-19 pandemic induced emergency online learning at undergraduate level: Evidence from undergraduate students from Dhaka City. Journal of Affective Disorders, 294(1). https://doi.org/10.1016/j.jad.2021.07.045.

Seibert, S. A. (2020). Problem-based learning: A strategy to foster generation Z's critical thinking and perseverance. Teaching and Learning in Nursing, 000, 2-5. https://doi.org/10.1016/j.teln.2020.09.002.

Shodiq, I. J., \& Zainiyati, H. S. (2020). Pemanfaatan Media Pembelajaran E-Learning Menggunakan Whastsapp Sebagai Solusi Ditengah Penyebaran Covid-19 Di Mi Nurulhuda Jelu. Al-Insyiroh: Jurnal Studi Keislaman, 6(2), 144-159. https://doi.org/10.35309/alinsyiroh.v6i2.3946.

Sidhu, R., \& Gage, W. H. (2021). Enhancing the odds of adopting e-learning or community-focused experiential learning as a teaching practice amongst university faculty. Heliyon, 7(4). https://doi.org/10.1016/j.heliyon.2021.e06704.

Slovaček, K. A., \& Čosić, G. (2020). The Role of Parents during the COVID19 Pandemic in Croatia. Studies in Educational Management, 8(8), 9-17. https://doi.org/10.32038/sem.2020.08.02.

Soisangwarn, A., \& Wongwanich, S. (2014). Promoting the Reflective Teacher through Peer Coaching to Improve Teaching Skills. Procedia - Social and Behavioral Sciences, 116. https://doi.org/10.1016/j.sbspro.2014.01.601.

Sonnenschein, S., Grossman, E. R., \& Grossman, J. A. (2021). U.S. parents' reports of assisting their children with distance learning during covid-19. Education Sciences, 11(9). https://doi.org/10.3390/educsci11090501.

Sumedi, \& Rovino. (2020). Speech Act Analysis Of English Teacher Talk at SMP Negeri 1 Rangkasbitung. Journal of English Language and Culture, 10(2). https://doi.org/10.30813/jelc.v10i2.2142.

Udayani, N. K. R. T. K., Wibawa, I. M. C., \& Rati, N. W. (2021). Development Of E-Comic Learning Media On The Topic Of The Human Digestive System. Journal of Education Technology, 5(3), 472-481. https://doi.org/10.23887/jet.v5i3.34732.

Vlachopoulos, D. (2020). COVID-19: Threat or Opportunity for Online Education? Higher Learning Research Communications, 10(1), 2. https://doi.org/10.18870/hlrc.v10i1.1179.

Windhiyana, E. (2020). Dampak Covid-19 Terhadap Kegiatan Pembelajaran Online Di Perguruan Tinggi Kristen Di Indonesia. Perspektif Ilmu Pendidikan, 34(1), 1-8. https://doi.org/10.21009/pip.341.1.

Yani, A. (2021). English teachers' perception on the quality of online learning during covid-19. Journal of English Language Teaching and Linguistics, 3(1). https://doi.org/10.21462/jeltl.v6i2.600.

Yati, F., \& Yaswinda, Y. (2019). Penerapan Model Evaluasi CIPPO dalam Mengevaluasi Penyelenggaraan Lembaga PAUD. Jurnal Obsesi Jurnal Pendidikan Anak Usia Dini, 4(1). https://doi.org/10.31004/obsesi.v4i1.238.

Yunita, V. M., Sunardi, \& Kristiyanto, A. (2021). Special Education Teachers 'Perceptions Toward Online Learning During the Covid-19 Pandemic. JPI (Jurnal Pendidikan Indonesia), 10(2), 202-211. https://doi.org/10.23887/jpi-undiksha.v10i2.29773.

Zalat, M. M., Hamed, M. S., \& Bolbol, S. A. (2021). The experiences, challenges, and acceptance of elearning as a tool for teaching during the COVID-19 pandemic among university medical staff. PLoS ONE, 16(3), 1-12. https://doi.org/10.1371/journal.pone.0248758. 